\title{
Family Tree
}

(from G. W. Bowersock, Julian the Apostate, Duckworth, 1978)

THE FAMILY OF JULIAN

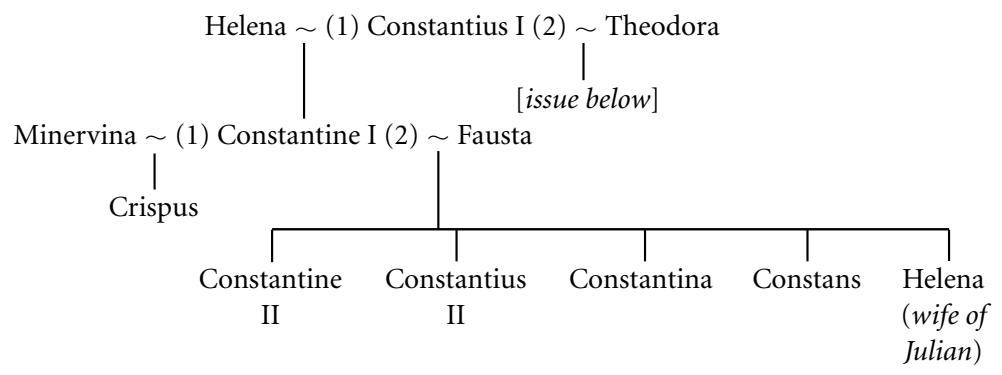

Helena $\sim(1)$ Constantius I $(2) \sim$ Theodora [issue above]

Basilina $\sim$ (2) Julius Constantius (1) Galla Julian
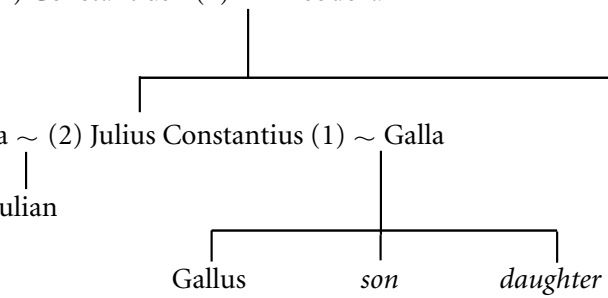

(second husband
of Constantina)
Constantius

Fl. Dalmatius Hannibalianus Constantia Eutropia Anastasia

Fl. Dalmatius Hannibalianus (first husband of Constantina) 